\title{
LIFE AND FERTILITY TABLES OF Pineus boerneri ANNAND (HEMIPTERA: ADELGIDAE) ON Pinus spp. (PINACEAE)
}

\author{
Josiane Teresinha Cardoso ${ }^{1 *}$, Sonia Maria Noemberg Lazzari ${ }^{2}$ \\ 1*Universidade do Estado de Santa Catarina, Lages, Santa Catarina, Brasil - josiane.cardoso@udesc.br \\ ${ }^{2}$ Universidade Federal do Paraná, Curitiba, Paraná, Brasil - lazzari @ufpr.br
}

Recebido para publicação: 06/10/2015 - Aceito para publicação: 03/03/2016

\begin{abstract}
Biological parameters of Pineus boerneri were evaluated in laboratory using seedlings of Pinus taeda and Pinus elliottii. The nymphs were observed along their development. The total life cycle was not significantly different on P. taeda and P. elliottii, being, respectively, 69 and 65 days. The same trend was observed for mean fecundity, being about 40 eggs/female on $P$. taeda and 53 on P. elliottii. However, when daily mean fecundity was considered, the difference was significant, being 1.3 eggs/female/day on $P$. taeda and 1.8 on $P$. elliottii. The nymphal mortality was greater on P. taeda $(50 \%)$ than on P. elliottii $(28 \%)$. These results reflected on life expectancy which was higher on $P$. elliottii for the nymphal stage, but for the adult stage there was no significant difference between both host plants. The intrinsic rate of natural increase and the finite rate of increase were similar, indicating that $P$. boerneri shows the same reproductive capacity on both hosts, despite the net reproductive rate being much greater on $P$. elliottii (23.8 eggs/female) than on $P$. taeda (15.4). The highest nymphal survival and reproductive rates on $P$. elliottii indicate that this host plant is more suitable for the development of $P$. boerneri.

Keywords: Insect biology; insect-plant interaction; pine wooly aphid.
\end{abstract}

\section{Resumo}

Tabelas de vida e de fertilidade de Pineus boerneri Annand (Hemiptera: Adelgidae) em Pinus spp. (Pinaceae). Parâmetros biológicos de Pineus boerneri foram avaliados em laboratório em mudas de Pinus taeda e Pinus elliottii. As ninfas foram acompanhadas durante seu desenvolvimento. O período total do ciclo de vida não diferiu significativamente nas duas espécies, respectivamente 69 dias em $P$. taeda e 65 em $P$. elliottii. O mesmo ocorreu com a fecundidade média, com 40 ovos/fêmea em $P$. taeda e 53 em $P$. elliottii. Porém, considerando a fecundidade média diária, houve diferença significativa com 1,3 ovos/fêmea/dia em $P$. taeda e 1,8 ovos/fêmea/dia em P. elliottii. A taxa de mortalidade ninfal foi mais alta em P. taeda (50\%) do que em P. elliottii (28\%). Esse padrão refletiu-se na esperança de vida que foi maior em P. elliottii no estágio ninfal, mas semelhante no estágio adulto nas duas plantas hospedeiras. A capacidade inata da espécie para aumentar em número e a razão finita de aumento foram semelhantes, indicando a mesma capacidade reprodutiva nos dois hospedeiros. A taxa líquida de reprodução foi significativamente maior em $P$. elliottii $(23,8$ ovos/fêmea) que em $P$. taeda $(15,4)$. As maiores taxas de sobrevivência ninfal e reprodutiva em $P$. elliottii evidenciam que esta planta é mais propícia para o desenvolvimento de $P$. boerneri.

Palavras-chave: Biologia do inseto; interação inseto-planta; pulgão-lanígero-do-pinus.

\section{INTRODUCTION}

The pine woolly aphid, Pineus boerneri Annand, 1928 (Hemiptera: Adelgidae), was first recorded in southern Brazil in 2000, in areas of Pinus plantation (Pinaceae) spreading rapidly to São Paulo and Minas Gerais (CARDOSO, 2007; IEDE et al., 2007; OLIVEIRA et al., 2008, LAZZARI et al., 2015). Pineus boerneri is an adelgid species spread over North America, South America, Africa, Asia and Oceania, infesting more than 40 species of Pinus, its exclusive host (MCCLURE, 1984; BLACKMAN; EASTOP, 1994; PETRO; MADOFFE, 2011; WYLIE; SPEIGHT, 2012; RODAS et al., 2015). In in East Asia, possibly area of its origin, P. boerneri occurs in low populations on Pinus thumbergii Parlatore, 1868, not causing any economic damage (MCCLURE, 1990). However, in areas such as the United States, Australia and some countries of Africa, P. boerneri causes considerable damage on commercial plantations of Pinus (TANTON; ALDER, 1977; MAILU, 1980; MCCLURE, 1984, 1989).

The taxonomic status of $P$. boerneri is not well defined and might have been described under different names in several parts of the world: Pineus laevis (Maskell) in New Zealand (EASTOP, 1966); P. laevis in Australia and Pineus pini Gmelin in Australia and Africa (EASTOP, 1966; BLACKMAN; EASTOP, 1994).

FLORESTA, Curitiba, PR, v. 46, n. 2, p. 251 - 258, abr. / jun. 2016.

Cardoso, J. T.; Lazzari, S. M. N.

ISSN eletrônico 1982-4688

DOI: $10.5380 /$ rf.v46i2.31384 
Tanton and Alder (1977) treat P. boerneri as P. laevis, forming the complex laevis/pini. Blackman and Eastop, (1994), however, treat P. laevis as a synonym of Pineu pini (Gmelin). According to these authors, the species described by Maskel, 1895 could be $P$. pini, which might occur simultaneously with $P$. boerneri in Australia and New Zealand, being confused due to morphological similarities.

The parthenogenetic oviparous female is the only known adult form in most parts of the world; it is apterous, sessile, and stays over the egg mass covered with wax threads secreted by glands in the head and thorax (MCCLURE, 1989; BLACKMAN; EASTOP, 1994; LAZZARI; CARDOSO, 2011; RODAS et al., 2015). McClure (1989) registered four nymphal instars for P. boerneri in the United States, while Yassen and Ghani (1971) found only three instars in Pakistan. First instar nymphs are crawlers and responsible for dispersion and choice of the feeding sites on the host plant (BLACKMAN; EASTOP, 1994).

Climatic conditions and host plant characteristics, besides the impact of natural enemies and genetic determinations are the main factors affecting the development of insect populations. In Pakistan, Yassen and Ghani (1971) recorded three or four annual generations of $P$. boerneri and observed that climatic conditions influence egg incubation, pre-reproductive and oviposition periods, as well as fecundity. Latent periods were observed for $1^{\text {st }}$ instar nymphs during the winter. In the United States, McClure (1989) detected variations in the duration of development along the seasons of the year.

Mailu et al. (1980) evaluated the biology of P. boerneri in field conditions in Kenya, and found a population mortality of $94 \%$ during lifetime, at egg stage $(72.5 \%)$, nymphs $(18.6 \%)$ and adults $(2.9 \%)$. They attributed the high mortality rates to factors such as infertility, predation, low dispersion capacity, desiccation, excess of rain, starvation, and excess of resin in the host plant.

The process of choosing a host plant by an aphid is quite complex, involving a great variety of factors such as age, physiology and architecture of the host plant, which affect the amount/availability of nutrients (SMITH, 2005; LAZZARI; ZONTA-DE-CARVALHO, 2009). In addition, the plant may have chemical and physical defenses that block the settlement of the insect (arrestants) or disrupt the feeding process (SMITH, 2005; NISHIDA, 2014).

Due to lack of biological data of P. boerneri and its relation to host plants in Brazil, this research aims to determine biological parameters and life and fertility tables of this potential pest on commercial species of Pinus.

\section{MATERIAL AND METHODS}

For this study, 58 seedlings of Pinus taeda L. and 42 of Pinus elliottii Engelm., approximately five months old, were cultivated in plastic tubes in the laboratory of the Department of Zoology at the Federal University of Paraná (UFPR). The seedlings were infested with P. boerneri and placed randomly in trays with water on a shelf near a window to receive natural light during daytime. Temperature averaged $21 \pm 2{ }^{\circ} \mathrm{C}$ and relative air humidity $53 \pm 7 \%$.

To start the experiments, eggs were obtained from adult females on infested seedlings. The area around each female was circled with a permanent marker and cleared up to facilitate removal of the eggs every 24 hours. Females were not removed because once they establish on a feeding site, they insert their stylets into the plant tissues and may break if removed. Each seedling was infested with 10 eggs and observed daily until emergence of the nymphs. From the second day on, the plants were examined under a magnifying glass. The site of establishment of each nymph was marked to facilitate the observation of the tiny individuals.

Biological parameters evaluated for $P$. boerneri were: incubation period and egg viability, number of nymphal instars based on body size and casted exuviae, duration of nymphal development. For the adult females, were evaluated: longevity, daily fecundity and mean number of eggs per female (total fecundity). The data obtained for both experiments were tabulated, transformed into $\sqrt{x+0,5}$, and the variance was analyzed by ANOVA. The averages were compared by the Tukey test at 5\% probability. Age-specific life table was calculated in software Tabvida (PENTEADO, 2007). The egg viability data were not included in the age-specific life and fertility table, because the $1^{\text {st }}$ instar nymphs disperse quickly and could not be counted. As a result, egg viability was considered to be $100 \%$.

To construct the age-specific life table, the following parameters were determined: survivor's' percentage (Lx); number of dead individuals (dx); age population structure (Ex); life expectation (ex); and death probability at age $\mathrm{x}(100 \mathrm{qx})$, where: $\mathrm{Ex}=[\mathrm{Lx}+(\mathrm{Lx}+1)] / 2 ; \mathrm{ex}=\mathrm{Tx} / \mathrm{Lx} ; 100 \mathrm{qx}=(\mathrm{dx} / \mathrm{Lx}) .100$.

To construct the fertility table, the values of age interval $(\mathrm{x})$, specific fertility $(\mathrm{mx})$ and survival probability (lx) were used for calculating the net reproductive rate (R0), the time interval between each generation $(\mathrm{T})$, the intrinsic rate of natural increase $(\mathrm{rm})$, the finite rate of increase $(\lambda)$, and the time for the 
population to double in number (DT), where: R0 $=\Sigma(\operatorname{mxlx}) ; \mathrm{T}=(\Sigma \mathrm{mx} . \mathrm{lx} . \mathrm{x}) /(\Sigma \mathrm{mx} . \mathrm{lx}) ; \mathrm{rm}=\operatorname{logeR} 0 / \mathrm{T}=\ln$ $\mathrm{RO} / \mathrm{T} ; \lambda=\mathrm{erm} ; \mathrm{TD}=\ln (2) / \mathrm{rm}$.

After tabulation of the data, the main indexes were represented graphically using Statistica version 5.5. Life expectation data were compared by $\mathrm{G}$ test at $5 \%$ probability. Variances of the indexes obtained from the fertility table were calculated using "Jackknife" and estimation (MANLY, 2006), and the averages compared by $\mathrm{T}$ test at $5 \%$ probability.

\section{RESULTS}

On P. taeda, a total of 447 eggs hatched (85.5\%), from 522 eggs, on 48 seedlings out of 58 infested. However, only 65 nymphs (12.5\%) established successfully and 52 were followed up along their development. In the experiment with $P$. elliottii, from the 364 eggs of $P$. boerneri placed on the seedlings, 289 hatched (79\%) with only 66 nymphs (18\%) establishing successfully and 46 followed up along their development. The mean egg incubation period was significantly shorter for $P$. elliottii in comparison to P. taeda (Table 1). The species presented four nymphal instars; only one single specimen underwent three instars.

Adult females stay on the top of the eggs, involving them with a great amount of wax threads, forming a woolly protection. The mean total number of eggs/female was 39.8 on P. taeda and 52.9 on P. elliottii, without significant difference among both host plants (Table 1). McClure (1984) registered similar number of eggs (45 eggs/female) for this same adelgid species on P. resinosa in the United States.

Table 1. Mean values and standard error for development parameters of Pineus boerneri (confidence interval at $95 \%$ ) reared on two host plants, under laboratory conditions, in Curitiba, $\mathrm{PR} ; 21 \pm 2{ }^{\circ} \mathrm{C}$ and relative air humidity of $53 \pm 7 \%$.

Tabela 1. Desenvolvimento de Pineus boerneri (média terro padrão e intervalo de confiança a 95\%) em duas espécies de plantas hospedeiras, em condições de laboratório, Curitiba, PR; $21 \pm 2{ }^{\circ} \mathrm{C}$ e umidade relativa do ar de $53 \pm 7 \%$.

\begin{tabular}{lll}
\hline Parameters & $P$. taeda $(\mathbf{n}=\mathbf{5 2})$ & $P$. elliottii $(\mathbf{n}=\mathbf{4 6})$ \\
\hline Eggs (days) & $7.5 \pm 0.1 \mathrm{~b}(7.2-7.8)$ & $6.2 \pm 0.1 \mathrm{a}(5.9-6.5)$ \\
$1^{\text {st }}$ instar (days) & $8.9 \pm 0.2 \mathrm{a}(8.5-9.3)$ & $11.0 \pm 0.3 \mathrm{~b}(10.5-11.63)$ \\
$2^{\text {nd }}$ instar (days) & $5.8 \pm 0.2 \mathrm{a}(5.3-6.3)$ & $5.8 \pm 0.2 \mathrm{a}(5.3-6.2)$ \\
$3^{\text {rd }}$ instar (days) & $6.7 \pm 0.9 \mathrm{a}(4.9-8.4)$ & $5.4 \pm 0.3 \mathrm{a}(4.8-6.0)$ \\
$4^{\text {th }}$ instar (days) & $5.1 \pm 0.5 \mathrm{a}(4.1-6.2)$ & $5.1 \pm 0.2 \mathrm{a}(4.5-5.6)$ \\
Total nymphal period (days)* & $24.5 \pm 0.8 \mathrm{a}(22.9-26.0)$ & $27.3 \pm 0.7 \mathrm{~b}(25.9-28.7)$ \\
Adult longevity (days) & $37.4 \pm 4.6 \mathrm{a}(27.94-46.82)$ & $31.7 \pm 3.4 \mathrm{a}(24.8-38.6)$ \\
Total life cycle (days)* & $69.1 \pm 4.5 \mathrm{a}(59.9-78.3)$ & $65.1 \pm 3.5 \mathrm{a}(57.9-72.4)$ \\
Oviposition period (days) & $32.2 \pm 4.4 \mathrm{a}(23.0-41.3)$ & $27.2 \pm 3.1 \mathrm{a}(20.8-33.6)$ \\
Fecundity (eggs/female) & $39.8 \pm 6.5 \mathrm{a}(26.4-53.3)$ & $52.9 \pm 8.3 \mathrm{a}(35.9-69.9)$ \\
Daily fecundity & $1.3 \pm 0.1 \mathrm{a}(1.1-1.6)$ & $1.8 \pm 0.1 \mathrm{~b}(1.5-2.1)$ \\
\hline
\end{tabular}

* The values of the total nymphal period and life cycle were calculated as an average of the complete data set, not the sum of the mean values. ** Different letters indicate significant differences on the line by the Tukey test $(\mathrm{p}<0,05 \%)$.

The life cycle of P. boerneri extended for approximately 69 days on P. taeda and 65 days on P. elliottii, without significant difference between the two hosts (Table 1). Mailu et al. (1980), recorded a life cycle of 75 days, under field conditions, with a temperature ranging from $19{ }^{\circ} \mathrm{C}$ to $24^{\circ} \mathrm{C}$. McClure (1989) observed a longer cycle, of 80 to 168 days, depending on the observed generation.

On P. taeda, the mortality rates $(\mathrm{dx})$ of $1^{\mathrm{st}}$ and $2^{\text {nd }}$ instar nymphs of $P$. boerneri was observed between the $18^{\text {th }}$ and $21^{\text {st }}$ day of life (three dead individuals) and between the $21^{\text {st }}$ and $24^{\text {th }}$ day (six dead), representing death probabilities of $6 \%$ and $13.3 \%$, respectively for the periods. High mortality rates were observed also in the $4^{\text {th }}$ instar and among teneral adults, between the $36^{\text {th }}$ and $39^{\text {th }}$ day $(5$ individuals - death probability of $15 \%$ for the period). There was $50 \%$ mortality during the nymphal stage, being $15.5 \%$ in the $1^{\text {st }}$ instar, $13.5 \%$ in the $2^{\text {nd }}$, $7.5 \%$ in the $3^{\text {rd }}$ and $13.5 \%$ in the $4^{\text {th }}$ instar.

On P. elliottii, the mortality rates $(\mathrm{dx})$ of $1^{\text {st }}$ and $2^{\text {nd }}$ instar nymphs also occurred between the $18^{\text {th }}$ and the $21^{\text {st }}$ day and between the $21^{\text {st }}$ and the $24^{\text {th }}$, respectively, with three deaths in each period. The death probability in both ages was $6.8 \%$ for the first and $7.3 \%$ for the second period. Again, it was observed a high 
mortality rate for $4^{\text {th }}$ instar nymphs and teneral adults, with death probability of $13.3 \%$. There was $28 \%$ mortality in the nymphal stage, being $6.4 \%$ in the $1^{\text {st }}$ instar, $8.7 \%$ in the $2^{\text {nd }}, 4.2 \%$ in $3^{\text {rd }}$, and $8.7 \%$ in the $4^{\text {th }}$ instar, similar to what was found for P. boerneri on P. taeda.

The life expectancy $\left(\mathrm{e}_{\mathrm{x}}\right)$, which relates the survival rate to the number of survivors, was higher on $P$. elliottii, 17.89, against 16.48 on P. taeda. This index presented the same pattern on both species of Pinus, being relatively high in the beginning and decreasing until the end of the evaluation period (Figures 1-2). The G test, applied to compare the two life tables, did not show significant differences in the parameters of survival of $P$. boerneri on both host plants, despite the higher mortality rate of nymphs on P. elliottii.
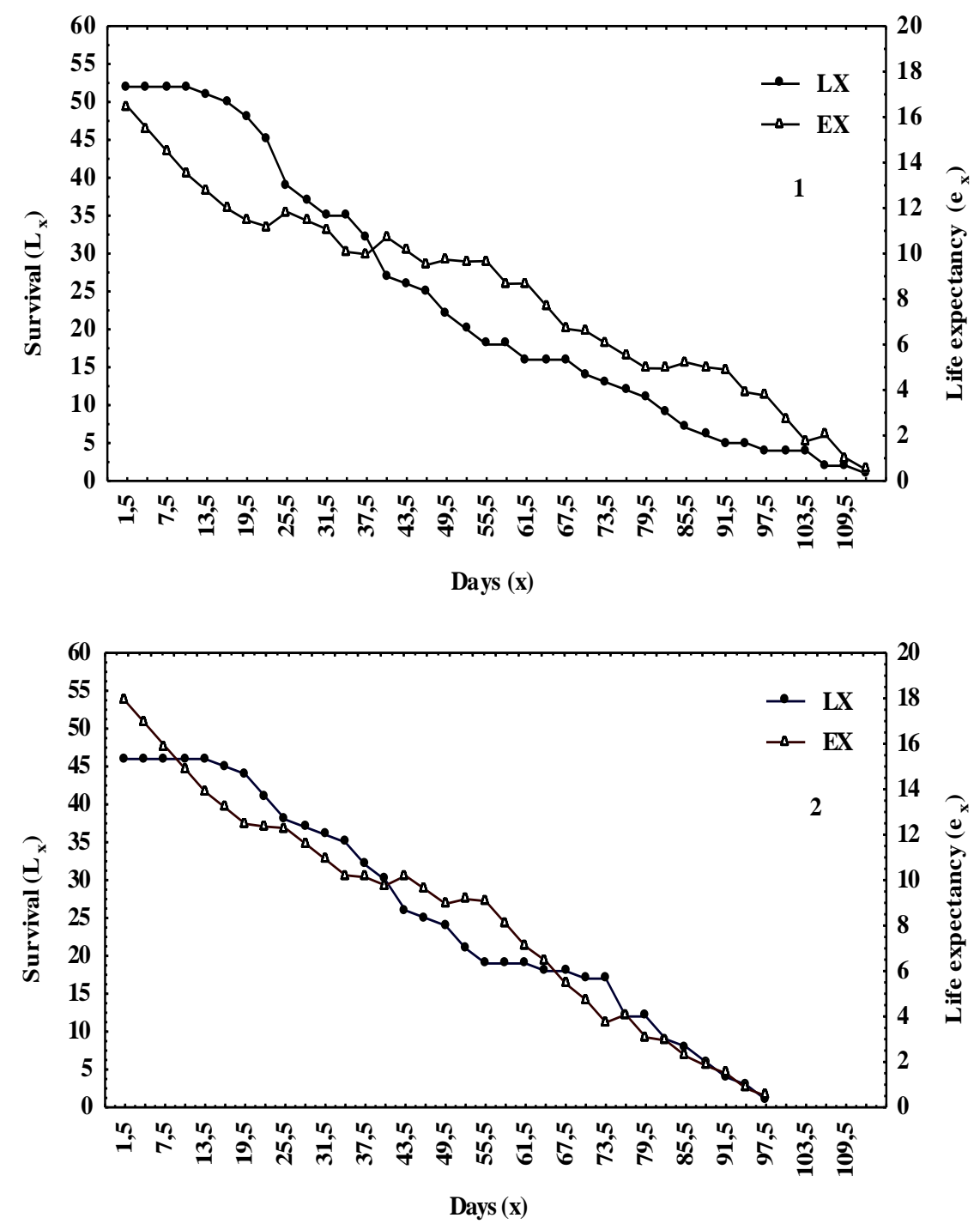

Figures 1-2. Number of survivors $\left(\mathrm{L}_{\mathrm{x}}\right)$ and life expectancy $\left(\mathrm{e}_{\mathrm{x}}\right)$ of Pineus boerneri reared on P. taeda (1) and $P$. elliottii (2) under laboratory conditions, in Curitiba, PR; $21 \pm 2{ }^{\circ} \mathrm{C}$ and relative air humidity of $53 \pm 7 \%$

Figuras 1-2. Número de sobreviventes (Lx) e esperança de vida (ex) de Pineus boerneri criados em P. taeda (1) e $P$. elliottii (2) em condições de laboratório, Curitiba, PR; $21 \pm 2{ }^{\circ} \mathrm{C}$ e umidade relativa do ar de $53 \pm 7 \%$.

The mean pre-reproductive and post-reproductive periods of $P$. boerneri females on $P$. taeda were 1.2 days and 3.5 days, respectively. On $P$. elliottii, these were 1.5 days and 2.6 days, respectively. On $P$. taeda, adult females entered the reproductive period by the $24^{\text {th }}$ day until the $108^{\text {th }}$ day of life (Figures 3-4). The highest fecundity rate $\left(\mathrm{m}_{\mathrm{x}}\right)$ of 3.6 eggs/female occurred between the $39^{\text {th }}$ to the $41^{\text {st }}$ day of life. On P. elliottii, females entered the reproductive period by the $27^{\text {th }}$ day until the $93^{\text {th }}$ day, with a higher $\mathrm{m}_{\mathrm{x}}$, but not differing statistically 
from the other host plant. The fecundity rate $\mathrm{m}_{\mathrm{x}}$ was observed to occur much later on $P$. elliottii, between the $54^{\text {th }}$ to the $57^{\text {th }}$ day, with the production of 6.58 eggs/female (Figures 3-4). The mean total number of eggs/female was 39.8 on P. taeda and 52.9 on P. elliottii, without significant difference among both host plants (Table 1).

The survival rate $\left(1_{\mathrm{x}}\right)$ of $P$. boerneri was similar on both host plants, decreasing gradually along lifetime (Figures 3-4); however, nymphal survival $\left(1_{\mathrm{x}}\right)$ was lower on $P$. taeda than on $P$. elliottii.
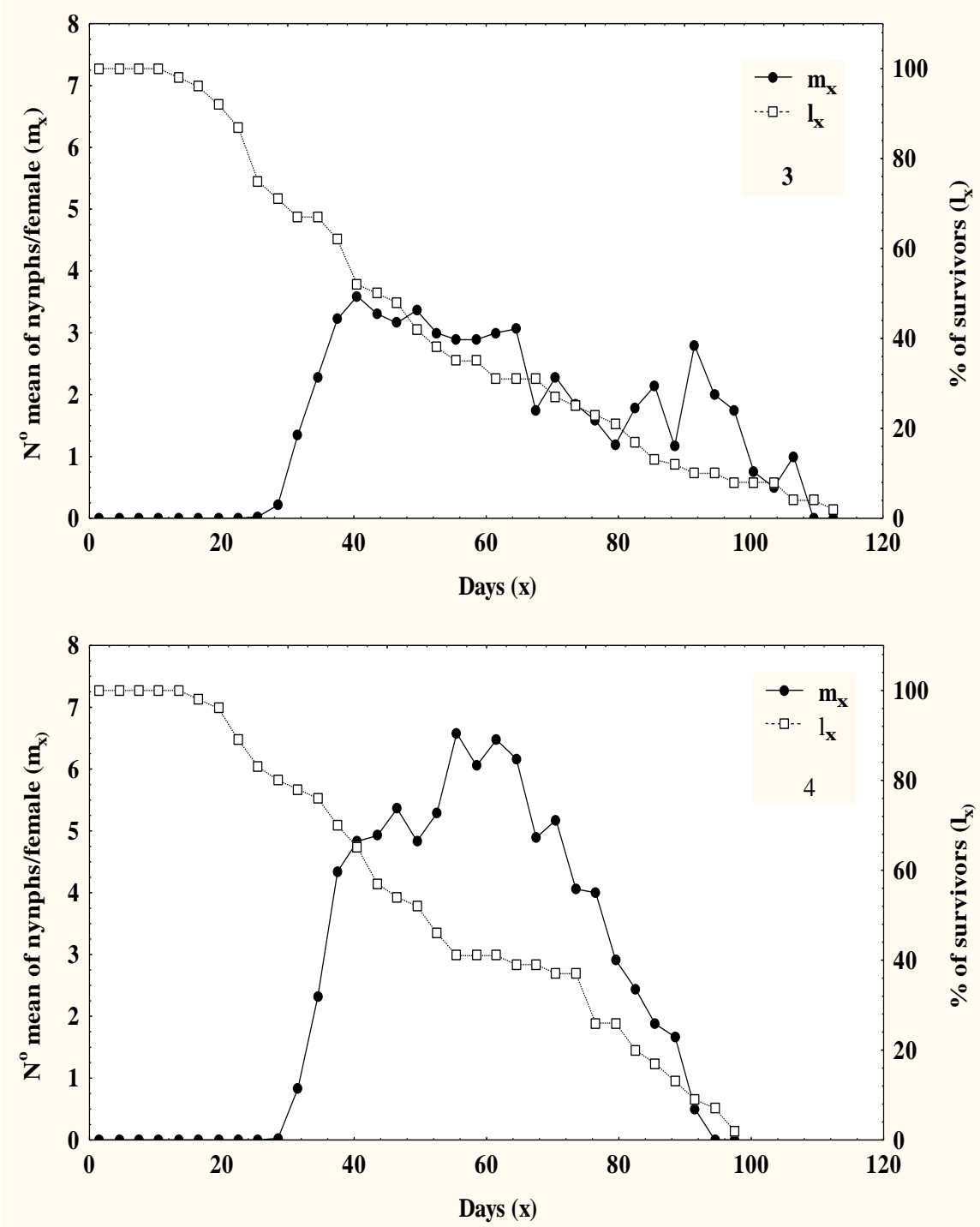

Figures 3-4. Mean number of nymphs produced by female $\left(\mathrm{m}_{\mathrm{x}}\right)$ and survival percentage $\left(\mathrm{l}_{\mathrm{x}}\right)$ of Pineus boerneri during their reproductive period, on $P$. taeda (2) and $P$. elliottii (3) under laboratory conditions, in Curitiba, PR; $21 \pm 2{ }^{\circ} \mathrm{C}$ and relative air humidity of $53 \pm 7 \%$.

Figuras 3-4. Número médio de ninfas produzidas por fêmea e porcentagem de sobrevivência (lx) de de Pineus boerneri em todo o período reprodutivo, em $P$. taeda (2) e P. elliottii (3) sob condições de laboratório, em Curitiba, $\mathrm{PR} ; 21 \pm 2{ }^{\circ} \mathrm{C}$ e umidade relativa do ar de $53 \pm 7 \%$.

The intrinsic rate of natural increase $\left(\mathrm{r}_{\mathrm{m}}\right)$ and the finite rate of increase $(\lambda)$, was similar for both host plants (Table 2). The intrinsic rate of natural increase was 0,06 for the both plants species and the finite rate of increase was 1.06 eggs/day on $P$. taeda and 1.07 eggs/day on $P$. elliottii.

The net reproduction rate $\left(\mathrm{R}_{0}\right)$ was statistically different among the specimens of $P$. boerneri reared on the two host plants: 23.8 eggs/female on $P$. elliottii and 15.41 eggs/female on $P$. taeda (Table 2). The mean generation time (T) of P. boerneri was significantly smaller on P. taeda (45.1 days) than on P. elliottii (49.2 days). Consequently, the time necessary for the species to duplicate in number of individuals is smaller on $P$. elliottii (Table 2). 
Table 2. Parameters of the life fertility table of Pineus boerneri (mean \pm standard error) on two hosts, under laboratory conditions, in Curitiba, PR; ; $21 \pm 2{ }^{\circ} \mathrm{C}$ and relative air humidity of $53 \pm 7 \%$. ( $\mathrm{x}=1$ day).

Tabela 2. Parâmetros da tabela de fertilidade de vida para Pineus boerneri (estimativa + erro padrão) em dois hospedeiros, sob condições de laboratório em Curitiba, PR; $21 \pm 2{ }^{\circ} \mathrm{C}$ e umidade relativa do ar de $53 \pm 7 \%$. ( $\mathrm{x}=1$ dia $)$.

\begin{tabular}{llllll}
\hline & $\mathrm{R}_{0}$ & $\mathrm{~T}$ & $\mathrm{r}_{\mathrm{m}}$ & $\lambda$ & $\mathrm{DT}$ \\
\hline Pinus taeda & $\begin{array}{l}15.41 \mathrm{a} \\
( \pm 0.09)\end{array}$ & $\begin{array}{l}45.09 \mathrm{a} \\
( \pm 0.04)\end{array}$ & $\begin{array}{l}0.06 \mathrm{a} \\
( \pm 0.0001)\end{array}$ & $\begin{array}{l}1.06 \mathrm{a} \\
( \pm 0.0001)\end{array}$ & $\begin{array}{l}11.43 \mathrm{a} \\
\pm 0.0001)\end{array}$ \\
Pinus elliottii & $\begin{array}{l}23.8 \mathrm{~b} \\
( \pm 0.09)\end{array}$ & $\begin{array}{l}49.2 \mathrm{~b} \\
( \pm 0.04)\end{array}$ & $\begin{array}{l}0.06 \mathrm{a} \\
( \pm 0.0001)\end{array}$ & $\begin{array}{l}1.07 \mathrm{a} \\
( \pm 0.0001)\end{array}$ & $( \pm 0.01)$ \\
\hline
\end{tabular}

$* \mathrm{R}_{0}=$ net reproduction rate; $\mathrm{T}=$ generation time; $\mathrm{r}_{\mathrm{m}}=$ intrinsic rate of natural increase; $\lambda=$ finite rate of increase; $\mathrm{DT}=\mathrm{doubling}$ time.

** Different letters indicate significant differences in the columns by the Tukey test $(\mathrm{p}<0,05 \%)$.

\section{DISCUSSION}

The mean egg incubation period was different between $P$. elliottii and $P$. taeda. The major causes of egg mortality to $P$. boerneri were desiccation, infertility, and eventual damage caused by handling due to their small size. Mailu et al. (1980), evaluating the biology for the specie in field conditions in Kenya, counted an average of $167 \mathrm{eggs} / \mathrm{cm}$ of the branch, but after two weeks only $461 \mathrm{st}$ instar nymphs were established (27.5\%). The authors mentioned that the main mortality factors were egg infertility, desiccation, rain, predators, nymph dispersion, and other unknown causes.

The number of nymphal instars agree with the observations of McClure (1989) for P. boerneri on Pinus resinosa Aiton in the United States. Yassen and Ghani (1971) detected three instars for both P. boerneri and Pineus sp. on Pinus roxburghii Sargent, in Pakistan.

The development time of $1^{\text {st }}$ instar nymphs was longer than that of the other instars. Also, it was longer on $P$. elliottii than on P. taeda. The reason of the prolonged period is because they take up to three days to find a place to settle down. Yassen and Ghani (1971) found a similar pattern for P. boerneri and Pineus wallichianae Yassen e Ghani, 1971, with the nymphs wandering for 2 to 3 days and 1 to 2 days, respectively, before establishing. On the other hand, McClure (1984) observed that $1^{\text {st }}$ instar nymphs of P. boerneri and Pineus coloradensis Gillette, 1907 found a feeding site soon after hatching.

In general, as the nymphs start feeding at a certain site, they become sessile for the rest of their lives. McClure (1984) also observed such behavior for P. boerneri and P. coloradensis. However, we observed that when the nymphs were disturbed during handling they would abandon that feeding site and eventually die.

The mortality rates $(\mathrm{dx})$ and the total mortality in the nymphal stage indicate that the nymphs of $P$. boerneri adapt better on $P$. elliottii than $P$. taeda. Mailu et al. (1980) determined the apparent mortality rate of $67 \%$ for nymphs of $P$. pini (=P. boerneri) in Kenya. This value was higher than ours, probably because they worked in field conditions, under the pressure of predators and no control of climatic factors.

The reproductive period and the total mean fecundity of $P$. boerneri on the two host plants was similar, although the daily mean fecundity was higher on $P$. elliottii. The pre-reproductive period of $P$. boerneri on $P$. roxburghii, Sarg. in Pakistan, ranged from few days to weeks, for different generations (YASSEN; GHANI 1971).

The intrinsic rate of natural increase ( $\mathrm{rm})$ is a measure of the multiplication rate of a species and depends on its intrinsic capacity of reproduction in a given environment. $P$. boerneri presented the same multiplication rate on both host plants, which suggests that the plants may not affect the reproductive capacity. Since this index was positive, we conclude that the populations are increasing and both host plants are equally favorable for the development of $P$. boerneri. Also, the finite rate of increase, which measures the number of individuals added to a population in a given period of time, was similar for both host plants and confirms the positive $\mathrm{rm}$.

The net reproduction rate (R0) was different for the both plants species and reflects on the high nymphal mortality recorded on $P$. taeda, with only $50 \%$ of the nymphs reaching the adult stage. On $P$. elliottii, the mortality was even higher, $72 \%$, which could explain why $P$. boerneri exhibits the same innate reproduction capacity on both host plants, but higher liquid reproduction rate on $P$. elliottii.

The net reproduction rate (R0) is the mean number of offspring produced per female in one generation; it takes in consideration the reproductive capacity and the individual survival and. This parameter was different among the specimens of $P$. boerneri reared on the two host plants and reflects on the high nymphal mortality recorded on $P$. taeda, with only $50 \%$ of the nymphs reaching the adult stage. On P. elliottii, the mortality was 
even higher, $72 \%$, which could explain why P. boerneri exhibits the same innate reproduction capacity on both host plants, but higher liquid reproduction rate on $P$. elliottii.

The mean generation time (T) shows that $P$. boerneri tends to increase its population more quickly when reared on $P$. elliottii than $P$. taeda. In fact, it was observed in laboratory that the seedlings of this plant species usually presented a larger number of colonies of $P$. boerneri.

It is known that fecundity rates and population growth of insects can be directly affected by chemical and morphological traits of their host plants, as well as their nutritional condition, such as the nitrogen level (LEATHER et al., 2005; AQUEEL; LEATHER, 2011; AQUEEL et al., 2014; NISHIDA, 2014). Leather et al. (2005) mention that host nutritional quality can affect the population dynamics of the aphid Drepanosiphum platanoidis (Schrank), mainly its growth rates and fertility. On the other hand, most insects have the capability of tolerating the toxins and allelochemicals produced as defense barriers by a host plant. The herbivore insect may exhibit particular behaviors and physiological and enzymatic counteraction mechanisms in order to survive (DESPRÉS et al. 2007). Although this research did not intend to investigate plant defense mechanisms, our results evidenced that $P$. elliottii was more favorable for pest population development, whereas $P$. taeda was more resistant against the development of $P$. boerneri.

Our study on the biology of $P$. boerneri reared on the most important commercial species of Pinus $(P$. taeda and $P$. elliottii) demonstrates the ability of this insect to reproduce and increase its population in few days, more successfully on $P$. elliottii and less on $P$. taeda. The information presented is fundamental for forestry management decisions, particularly in the selection/cultivation of more resistant species or varieties of pines in order to prevent the outbreak of pine wooly aphid populations and damage that might follow.

\section{CONCLUSION}

- The significantly greater reproductive rates and survival times of nymphs and adults of P. boerneri reared on $P$. elliottii indicates that this plant species is less resistant to infestation by pine wooly aphids.

- $\quad$ The life and survival tables confirm that P. boerneri is better adapted to P. elliottii than to P.taeda.

\section{ACKNOWLEDGMENTS}

This study was partially supported by a grant from CNPq-Brazil. Contribution $\mathrm{N}^{\mathrm{o}} 1826$ of the Departamento de Zoologia, Universidade Federal do Paraná, Brazil.

\section{REFERENCES}

AQUEEL, M. A.; LEATHER, S. R. Effect of nitrogen fertil-izer on the growth and survival of Rhopalosiphum padi (L.) and Sitobion avenae (F.) (Homoptera: Aphididae) on different wheat cultivars. Crop Protection, Queensland, v. 30, p. 216 - 221, 2011.

AQUEEL, M. A.; COLLINS, C. M.; RAZA, A. B. M.; AHMAD, S.; TARIQ, M.; LEATHER, S. R. Effect of plant nutrition on aphid size, prey consumption, and life history characteristics of green lacewing, Insect Science, v. 21, p. 74 - 82, 2014.

BLACKMAN, R. L.; EASTOP, V. F. Aphids on the world's trees: an identification and information guide. Wallingford: CAB International, 1994. 987 p.

CARDOSO, J. T. Morfologia, bioecologia e comportamento alimentar de Pineus boerneri Annand, 1928 (Hemiptera: Aphididae) em Pinus spp. (Pinacea). 135 f. Tese (Doutorado em Ciências Biológicas Concentração em Entomologia) - Universidade Federal do Paraná, Curitiba, 2007.

DESPRES, L.; DAVID, J. P.; GALLET, C. The evolutionary ecology of insect resistance to plant chemicals. Trends in Ecology and Evolution, v. 22, p. 298 - 307, 2007.

EASTOP, V. F. A taxonomic study of Australian Aphidoidea (Homoptera). Australian Journal of Zoology, East Melbourne, v. 14, p. 399 - 592, 1966.

IEDE, E. T.; PENTEADO, S. R. C.; CALDATO, N.; REIS-FILHO, W. Pineus boerneri (Hemiptera: Adelgidae) - pulgão-lanígero-do-pínus - praga introduzida em plantios de Pinus spp. no Brasil. Colombo: Comunicado Técnico 190, Embrapa Florestas, 2007, 6 p.

LAZZARI, S. M. N.; ZONTA-DE-CARVALHO, R. C. Sugadores de Seiva (Aphidoidea). In: PANIZZI, A. R.; 
PARRA, J. R. P. Bioecologia e nutrição de insetos: Base para o manejo integrado de pragas. Brasília, 2009, p. $767-836$.

LAZZARI, S. M. N; CARDOSO, J. T. Pineus boerneri Annand, 1928 (Hemiptera: Adelgidae) - a new species to Brazil: morphology of eggs, nymphs and adults. Revista Brasileira de Entomologia, Curitiba, v. 55, p. 459 466, 2011.

LAZZARI, S. M. N.; CARDOSO, J. T.; PENTEADO, S. R. C.; ZONTA-DE-CARVALHO, R. C.; LAZZAROTTO, C. M. Pulgão-lanígero-do-pínus, Pineus boerneri Annand. In: VILELA, E. F.; ZUCCHI, R. A. Pragas introduzidas no Brasil: insetos e ácaros. Piracicaba: Ed. FEALQ, 2015, 908 p.

LEATHER, S. R.; WADE, F. A.; GODFRAY, H. C. J. Plant quality, progeny sequence, and the sex ratio of the sycamore aphid, Drepanosiphum platanoidis. Entomologia Experimentalis et Applicata, Amsterdam, v. 115, p. $311-321,2005$.

MAILU, A. M.; KHAMAL, C. P. M.; ROSE, D. J.W. Population dynamics of pine wooly aphid, Pineus pini (Gmelin) (Hemiptera: Adelgidae) in Kenya. Bulletin of Entomological Research, London, v. 70, p. 483 - 490 , 1980.

MANLY, B. F. J. Randomization, Bootstrap and Monte Carlo Methods in Biology. London: Chapman and Hall/CRC, 3ed. 2006, 480 p.

MCCLURE, M. S. Influence of cohabitation and resinosis on site selection and survival of Pineus boerneri Annand and P. coloradensis (Gilette) (Homoptera: Adelgidae) on red pine. Environmental Entomology, Lanhan, v. 13, p. 657 - 663, 1984.

MCCLURE, M. S. Biology, population trends and damage of Pineus boerneri and P. coloradensis (Homoptera: Adelgidae) on red pine. Environmental Entomology, Lanhan, v. 18, p. 1066 - 1073, 1989.

MCCLURE, M. S. Cohabitation and host species effects on the population growth of Matsucoccus resinosa (Homoptera: Margarodidae) and Pineus boerneri (Homoptera: Adelgidae) on red pine. Environmental Entomology, Lanhan, v. 19, p. 672 - 676, 1990.

NISHIDA, R. Chemical ecology of insect-plant interactions: ecological significance of plant secondary metabolites. Bioscience, Biotechnology, and Biochemistry, London, v. 78, p. 1, 2014.

OLIVEIRA, N. C.; WILCKEN, C. F.; ZONTA-DE-CARVALHO, R. C.; FERREIRA-FILHO, P. J.; COUTO, E. B. Ocorrência de Pineus boerneri Annand (Hemiptera: Adelgidae) em Pinus spp. nos Estados de São Paulo e Minas Gerais. Arquivos do Instituto Biológico, São Paulo, v. 75, p. 385 - 387, 2008.

PENTEADO, S. R. C. Cinara atlântica (Wilson) (Hemiptera, Aphididea): um estudo de biologia e associações. 250 p. Tese (Doutorado em Ciências Biológicas - Concentração em Entomologia) - Universidade Federal do Paraná, Curiltiba, 2007.

PETRO, R.; MADOFFE, S. S. Status of Pine Woolly Aphid (Pineus boerneri) in Sao-Hill Forest Plantation, Tanzania. Journal of Entomology, v. 8, p. 468 - 475, 2011.

RODAS, C. A.; SERNA, R.; BOLAÑOS, M. D.; GRANADOS, G. M.; WINGFIELD, M. J.; HURLEY, B. P. Biology, incidence and host susceptibility of Pineus boerneri (Hemiptera: Adelgidae) in Colombian pine plantations. Southern Forests. Disponível em: http://www.tandfonline.com/doi/abs/10.2989/20702620.2014.10 01662 Acesso em: 31/08/2015.

SMITH, M. C. Plant resistance to arthropods - Molecular and conventional approaches. Netherlands: Springer, 2005. $423 \mathrm{p}$.

TANTON, M. T.; ALDER, D. The distribution and possible effects of the woolly aphid Pineus (Homoptera: Adelgidae) on Pinus radiata D. Don growing in the Australian capital territory. Australian Forest Research, East Melbourne, v. 7, p. 253 - 263, 1977.

WYLIE, F. R.; SPEIGHT, M. R. Insect pests in tropical forestry. New York: CABI Publishing, 2 ed. 2012 , $376 \mathrm{p}$.

YASSEN, M.; GHANI, M. A. Descriptions and notes on the biology of four new species of Adelgidae from West Pakistan. Bulletin of Entomological Research, London, v. 61, p. 191 - 205, 1971. 